MICHIGAN RETIREMENT AND DISABILITY RESEARCH CENTER UNIVERSITY OF MICHIGAN

Promoting research on retirement, disability, and Social Security policy

\title{
Saving Regret: Self-assessed Life-cycle Saving Behavior in the U.S. and Singapore
}

Axel Börsch-Supan, Michael D. Hurd, and Susann Rohwedder

MRDRC WP 2020-413

UM20-17 


\title{
Saving Regret: Self-assessed Life-cycle Saving Behavior in the United States and Singapore
}

\author{
Axel Börsch-Supan \\ MEA, TUM and NBER

\section{Susann Rohwedder} \\ RAND and NETSPAR
}

Michael D. Hurd

RAND, NBER and NETSPAR

\section{September 2020}

Michigan Retirement and Disability Research Center, University of Michigan, P.O. Box 1248. Ann Arbor, Ml 48104, mrdrc.isr.umich.edu, (734) 615-0422

\section{Acknowledgements}

The research reported herein was performed pursuant to a grant from the U.S. Social Security Administration (SSA) funded as part of the Retirement and Disability Research Consortium through the University of Michigan Retirement and Disability Research Center Award RDR18000002-02. The opinions and conclusions expressed are solely those of the author(s) and do not represent the opinions or policy of SSA or any agency of the federal government. Neither the United States government nor any agency thereof, nor any of their employees, makes any warranty, express or implied, or assumes any legal liability or responsibility for the accuracy, completeness, or usefulness of the contents of this report. Reference herein to any specific commercial product, process or service by trade name, trademark, manufacturer, or otherwise does not necessarily constitute or imply endorsement, recommendation or favoring by the United States government or any agency thereof.

\section{Regents of the University of Michigan}

Jordan B. Acker; Huntington Woods; Michael J. Behm, Grand Blanc; Mark J. Bernstein, Ann Arbor; Paul W. Brown, Ann Arbor; Shauna Ryder Diggs, Grosse Pointe; Denise llitch, Bingham Farms; Ron Weiser, Ann Arbor; Katherine E. White, Ann Arbor; Mark S. Schlissel, ex officio 


\title{
Saving Regret: Self-assessed Life-cycle Saving Behavior in the United States and Singapore
}

\begin{abstract}
Based on the belief that many people have under-saved and that the reason for under-saving is procrastination, paternalistic nudging to foster saving is often advocated by policy researchers. However, there is little empirical evidence that on hindsight individuals would wish to have saved more than they did, which is an implication of under-saving due to procrastination. To fill this empirical gap, we fielded surveys in the RAND American Life Panel and in the Singapore Life Panel. We asked persons ages 60 to 74 whether, if they were given the chance to do it over again, they would have saved differently earlier in their lives. If they wished to have saved more, we say they have "saving regret." We also fielded a psychometric battery designed to classify people according to their tendency to procrastinate. We found both in the United States and in the Singapore data that about half the population expressed saving regret with the proportion being higher in the U.S. The likelihood of expressing regret was uncorrelated with our measures of procrastination: That is, individuals who affirm statements that plainly indicate a tendency to put off difficult tasks are no more likely to express saving regret than individuals who do not have that tendency. We also asked respondents whether, over their lifetimes, they had experienced unexpected events or shocks that harmed their economic situation, such as unemployment. Substantially higher fractions of the U.S. sample experienced such shocks. That experience explained the greater frequency of saving regret in the U.S.
\end{abstract}

\section{Citation}

Börsch-Supan, Axel, Michael D. Hurd, and Susann Rohwedder. 2020. "Saving Regret: Selfassessed Life-cycle Saving Behavior in the U.S. and Singapore." Ann Arbor, MI. University of Michigan Retirement and Disability Research Center (MRDRC) Working Paper; MRDRC WP 2020-413. https://mrdrc.isr.umich.edu/publications/papers/pdf/wp413.pdf

\section{Authors' acknowledgements}

Data collection of the SLP was funded by the Singapore Ministry of Education under grant number MOE2013-T3-1-009 to the Singapore Management University. Data collection of the ALP modules used in this study was funded by the National Institute on Aging (P01 AG008291) with additional funding from the Max Planck Society. Jessica Hayes provided excellent programming assistance. 


\section{Introduction}

A number of research papers advocate paternalistic nudging to foster saving, especially to increase economic resources in old age (Thaler 1994;Thaler and Shefrin, 1981; Laibson 1997, 1998; Laibson et al., 1998; Thaler and Sunstein 2003, 2009; Lewis 2008; Chetty et al., 2014). A justification for these interventions is the belief that many people have under-saved and that the reason for under-saving is that often people procrastinate, particularly about saving. An implication is that on hindsight, the preferred choice of such persons would be to have saved more than they actually did. However, there is little empirical evidence on the saving behavior that individuals would have chosen on hindsight.

To fill this empirical gap, we fielded two surveys in the RAND American Life Panel (ALP). We asked persons ages 60 to 74 whether, if they were given the chance to do it over again, they would have saved differently earlier in their lives. If they would have wanted to have saved more, we say they have "saving regret."

In May 2018, we fielded a similar survey to $60-74$ year old participants of the Singapore Life Panel (SLP) ${ }^{1}$, which is modelled on the ALP Financial Crisis Surveys. Viewed in international context, Singapore is similar to the U.S. in encouraging selfreliance, but it has a smaller safety net and the institutions surrounding economic preparation for retirement are very different. In particular, Singapore mandates a total contribution rate of $37 \%$ of earnings (employee and employer combined) for most

\footnotetext{
${ }^{1}$ Data collection of the SLP was funded by the Singapore Ministry of Education under grant number MOE2013-T3-1-009 to the Singapore Management University.
} 
workers into funds managed by the Central Provident Fund. These funds finance consumption in retirement and health care both pre- and post-retirement. They can also be used for financing the purchase of a home. There are very few defined benefit (DB) pension plans, no Social Security, limited public health insurance, and no unemployment insurance.

We use the data from the ALP and the SLP to compare saving regret in the U.S. with that in Singapore and to shed light on the mechanisms leading to saving regret and how these may interact with the policy environment. Because of the high level of mandated saving in Singapore, procrastination would appear to be irrelevant, possibly bringing the role of financial risks over the lifecycle into focus. This raises the questions of the roles of uncertainty and the individual's ability to manage unexpected financial shocks in shaping retirement saving outcomes and how do these differ in Singapore and the U.S.

\section{Background about Singapore}

For many years Singapore has experienced strong economic growth: GDP per capita was $\$ 12,400$ in 1979 and $\$ 58,800$ in 2019 (both in 2010 USD). It experienced similarly strong growth in education. In 2015 , for example, only $25 \%$ of 65 to 69 year

olds in Singapore had some post-secondary education, while $45 \%$ of 50 to 54 year olds did. This implies that in 15 years the proportion of the population attending at least some college increased 20-percentage points.

The Singapore's economy is strongly market based but with significant policy interventions at several key points. The most important intervention for saving behavior is the Central Provident Fund (CPF) operated by the Singapore Government. While 
there is some variation by age and cohort, for most workers $37 \%$ of earnings is mandated to be contributed to the CPF, about half paid by the employee and half by the employer. These contributions are on a pre-tax basis (tax advantaged). They are paid into three accounts. First, about half the mandated contribution is deposited into the Ordinary Account. This account may be used for investment and for purchasing housing and servicing a mortgage, even during the working life. Unspent funds from this account may be used to support retirement spending. Second, about one-fourth of the total contribution is paid into the Special Account, which is savings for retirement. These funds cannot be withdrawn before age 55 . Thus about $9 \%$ of earnings are dedicated solely to retirement, slightly less than what is paid into U.S. Social Security for retirement (about 10\%). Both the Special Account and the Ordinary Account are defined contribution (DC) pension schemes, so that, unlike the U.S. Social Security system, they lack progressivity. Third, the remaining one-fourth of contributions are paid into the MediSave account, used for health care insurance and spending on health care during working life and in retirement. The MediSave account can also be used to fund family members' health care insurance and health care spending. At age 55 , a fourth account, the Retirement Account, is established using monies from the Special Account and the Ordinary Account. There is a required minimum that must be deposited into the Retirement Account. At age 65 or at least by age 70, a mandated minimum amount of the Retirement Account must be converted to an annuity.

The savings in the Ordinary and Special accounts (about $27 \%$ of earnings) would appear to be adequate to finance retirement, but apparently much of the Ordinary Account savings have been used to finance the purchase of housing. Housing is quite 
expensive in Singapore, resulting in a high concentration of wealth in housing: Our SLP sample shows that Singaporeans 50 to 70 years old in 2018 had median housing wealth of about $\$ 377,000$ (converted to 2018 U.S. dollars using purchasing power parity) ${ }^{2}$ and median total wealth of $\$ 613,000$. To put these values into perspective, we note that median income of Singapore couples shortly before retirement (ages 50 to 55 ) was about $\$ 47,000$.

All persons can buy subsidized health care insurance that aims to cover costs in public hospitals and clinics, which perhaps are of lower quality. Lower-income persons can be subsidized further. Higher-income persons can buy additional integrated plans; $68 \%$ of the population purchases such plans, which cover private hospitals and better wards. The insurance purchase can be made from the MediSave account.

Most assets in CPF accounts earn interest above market rates. CPF account holders have some ability to invest in stocks and other limited vehicles, but mostly the funds are interest bearing. Retirement is financed by the CPF account and any private savings. Private pensions are rare.

The "Retirement Age" is currently 62, having been increased from age 60 in 1993. Employers may not dismiss employees on grounds of age before the retirement age of age 62. The retirement age is to be raised in steps to 65 beginning in 2022 . Employees work on contracts, which often have end dates at specific ages, particularly age 62 and 65.

\footnotetext{
${ }^{2}$ The conversion is to multiply the Singapore dollar by 0.94 . According to the actual exchange
} rate the Singapore dollar is worth about 0.73 U.S. dollar. 
Singapore has a policy to encourage later retirement, the Retirement and Reemployment Act (RRA). The RRA was introduced in 2007, but not enacted until 2012. The employers of workers whose contracts ended between the ages of 62 and 65 were encouraged to extend their contracts either in one shot or in a series of one-year contracts to the Re-employment Age, which was specified in the RRA act to be age 65 . The new contract may be subject to negotiation, resulting in a change in duties or a wage reduction within limits. The employer has an incentive to "re-employ" the worker because of penalties that could be imposed should an unwillingness to re-employ not be justified. Satisfactory reasons for not re-employing would include health conditions or poor job performance.

The Re-Employment Age was increased to age 67 in 2017, and is scheduled to increase to age 70 in steps beginning in 2022. Likely as a result of the discussion surrounding the RRA, labor force participation at older ages increased sharply even before the formal enactment in 2012: In 2005 the labor force participation rate of men 60 to 64 was $52.5 \%$ and of women was $21.3 \%$; in 2019 , these rates were $76.7 \%$ for men and $50.7 \%$ for women.

There is no public unemployment insurance in Singapore. The stated aim of the government is to help with re-employment. But some long-term unemployment exists (Hurd and Rohwedder 2018). 


\section{Data}

\section{The RAND American Life Panel}

The ALP is a standing panel of about 6,000 individuals 18 and older who are invited to take a survey over the internet from time to time. Individuals are recruited into the panel in a way to enhance population representation. The panel has been active in its current form since 2006, so that data from hundreds of surveys are available and can be linked to individuals, greatly expanding the types of analyses that can be performed on data from any particular wave. See Pollard and Baird (2017) for details on sample recruitment, response rates, retention, and weighting.

We designed ALP survey 455, fielded in August-December 2016 to respondents 60 or older. We obtained 1,728 completed interviews ( $72.3 \%$ response rate). The questionnaire began with sociodemographic and economic characteristics, a psychometric battery for personal characteristics, including procrastination, and a set of questions about the respondents' assessments of their income and living standards. To elicit individuals' hindsight assessment of their saving behavior, we prompted them to look back to when they were around 45 years old and to say whether they wished they had saved more, about the same, or less earlier in life if given the chance to re-do their saving and spending. Specifically, we asked

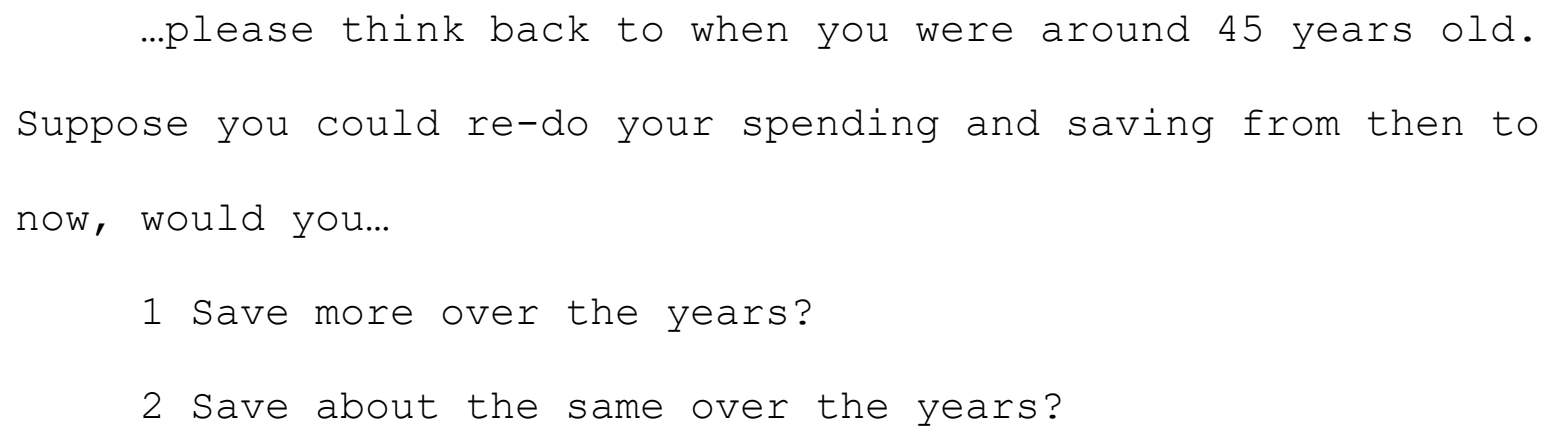




\section{Save less over the years?}

We call the choice of 1 "saving regret."

We conducted a design experiment in ALP. For a random $50 \%$ of respondents we modified response 1 to:

1 Spend less and save more over the years?

to remind respondents that saving more would require a reduction in spending. We call this the "framed" version. Framing resulted in a reduction of regret of about 7percentage points. Our objective in the framing was to reduce or even avoid "cheap talk."

For those who expressed regret we followed up with a list of categories of spending items such as housing, food, or clothing and asked which of them could have been reduced. We included a response of

No way we could have cut spending. We could not have saved more

in which case we recoded the respondent as not expressing saving regret. The objective of the follow-up questions was to reduce "cheap talk" further; that is, to remind, perhaps more forcefully, that saving more would require spending less.

We fielded a second survey from December 2017 to February 2018 in which we asked again about saving regret. We used the framed version only, and used the followup about categories of spending that could be reduced. In most of the results presented in this paper, we pool the responses from the two ALP surveys and account for the effect on the standard errors of a repeated observation on the overlap cases $(2,111$ individuals out of the 2,290 individuals in the second wave). Based on our experience from the first survey, we modified several of the questions in the second wave: So for 
some of the analyses, we only use observations from the second wave and from the overlap cases in the first wave. For these analyses over this modestly reduced data set we have an identical survey design in the ALP and the SLP.

To measure an individual-level lack of will-power to follow through on personal commitments or a tendency to procrastinate, we asked a series of questions in wave 1 about an individual's self-perception of his or her ability to accomplish difficult tasks and about whether in past or ongoing actions the person had or does procrastinate. We call these "psychometric" variables. They were derived from the General Procrastination Scale (GPS) described and validated by Tuckman (1991). We asked respondents to evaluate themselves along several dimensions, such as a self-assessment of their general and financial planning behavior and motivations. A first set of five questions used the following format:

Do you agree or disagree with the following statements?

The first question was

People should do what they like today rather than putting

it off until tomorrow.

1 strongly disagree

2 Disagree

3 Neither agree or disagree

4 Agree

5 Strongly agree

This question was followed with four additional attitudinal questions. See Table 3 (Panel A) for the complete list. 
that when comparing the frequency of shocks or the saving regret associated with shocks between the ALP and the SLP, we will confine the sample to those who were in ALP wave 2. For the overlap cases, however, we use their report of saving regret from both waves along with their report of shocks from Wave $2 .^{3}$

Taking both ALP waves together, we have 2,618 respondents in our age range, 60 to 74 . Of them 2111 were in both waves (overlap cases), 328 in Wave 1 but not in Wave 2, and 179 in Wave 2 but not in Wave 1.

\section{The Singapore Life Panel}

The Singapore Life Panel (SLP) is a monthly, internet-based survey representative of the Singapore population ages 50 to 70 (and their spouses) when first recruited in 2016. The SLP was modeled in many ways after the ALP Financial Crisis Surveys, a series of monthly interviews that Hurd and Rohwedder launched in the ALP in May 2009 (Hurd and Rohwedder 2015). The SLP has a core of regular monthly questions, some additional regular quarterly content, plus rotating modules. In January it obtains a complete assessment of income during the preceding year and a complete balance sheet of assets. The SLP has consistently high response rates, obtaining about 8,000 interviews every month (Vaithianathan et al. 2018).

In May 2018, we fielded a survey in the SLP on saving regret. We aimed to obtain data elicited in exactly the same way as in Wave 2 of the ALP survey. We asked about saving regret in the framed version, as in Wave 2. We asked the same

\footnotetext{
${ }^{3}$ Because of observation error or reporting error, the Wave 2 response contains additional information, but the standard error must be adjusted for a second report from the same respondent.
} 
psychometrics questions, the same measures of planning horizon, financial literacy and probability numeracy, and about the same shocks. We obtained 4,559 responses in our age range, 60 to 74 .

\section{Results}

Table 1 shows the percent of respondents expressing regret in the ALP and in the SLP, both before and after revision. Both populations reduced regret when asked what types of spending could have been reduced, the ALP by about 12 percentage points and the SLP by 8 percentage points. Fewer Singaporeans than Americans wished they had saved more: Very few in either country would have saved less.

Table 2 shows the variation in saving regret as a function of demographic, social, and economic characteristics. In both countries there is little difference between men and women.

In the U.S. there is a monotonic age gradient: Age is associated with less regret, and the difference between the oldest and the youngest age band is statistically significant. That pattern is not found in Singapore.

The population distribution by marital status is quite different in Singapore:

Divorce is 11 percentage points lower and "never married" five percentage points higher than in the U.S. Among those in the U.S., higher proportions of those who are separated, divorced, or widowed express saving regret. This is in line with the wellknown economic status of those groups: Particularly, divorced or separated women have fewer economic resources. This pattern by marital status is not evident in Singapore. 
Because the educational levels in the two countries are quite different, we divided educational attainment into terciles. Given the large number of U.S. respondents who have completed high school but no further education, we used randomization to achieve the equal allocations. ${ }^{4}$ In the U.S., those in the middle educational tercile expressed regret with the greatest frequency. In Singapore, there is no education gradient.

In both countries, those in the highest wealth quartile are the least likely to express saving regret, with the difference between the highest wealth quartile and the others being greater in the ALP than in the SLP. ${ }^{5}$ There is little variation in saving regret by income in either country. In Singapore, those in fair or poor self-assessed health are more likely to express regret. This pattern is also observed in the U.S., but the difference is not statistically significant.

Based on the extensive literature that explains under-saving using behavioral explanations, we expected to see systematic and large variation in saving regret as a function of self-rated characteristics for procrastination, lack of self-control, and present bias. In Table 3 we show how saving regret varies by such measures of personal traits.

The first five traits are meant to measure self-confidence and a focus on the present. Because of very few responses in some of the categories, we collapsed the five response categories (strongly disagree, disagree, neither agree nor disagree, agree, strongly agree) into three categories (strongly disagree and disagree, neither

\footnotetext{
${ }^{4}$ In the ALP the lowest tercile is mostly composed of those who completed high school, whereas in the SLP, it is mostly composed of those with a primary education only.

${ }^{5}$ The large number of missing values in the ALP are due to wealth data being collected in a different wave of the ALP. It is only in the overlap cases that we have a wealth measure.
} 
agree nor disagree, agree and strongly agree). Of interest, first, is the distribution of the populations across the response categories. The SLP responses are split evenly between the three categories, whereas the ALP responses are strongly shifted toward "disagree." The other notable difference is the response to the statement "For the sake of my health, I stay away from unhealthy foods or behaviors that I might enjoy." Some $35 \%$ of ALP respondents agreed with that statement compared with $64 \%$ of SLP respondents. The distribution of responses to the other three categories are similar across the two populations.

When we consider the relationship between the responses to the characteristics and the expressing of saving regret, we find little correlation. For each of the five characteristics in Panel A, we estimated the mean expression of regret over each of the three response categories, and we make comparisons between the reference category, the category with the most observations, and the other two categories, for a total of 10 comparisons. In the ALP, there were no significant differences in saving regret. In the SLP, there were seven significant differences in two-sided tests at the $5 \%$ level, but just three of them had the expected sign, that is an increase in regret for an increase in a measure of a focus on the present. For example, $48 \%$ of those agreeing with "People should do what they like today rather than putting it off until tomorrow" expressed saving regret compared with $41 \%$ of those disagreeing and $40 \%$ of those neither agreeing nor disagreeing. That is, people with a greater focus on the present were somewhat more likely to express regret. However, in the other four significant comparisons, the sign of the difference did not align with expectations. For example, among those who agreed with the statement "For the sake of my health, I stay away from unhealthy foods or 
behaviors that I might enjoy," $49 \%$ expressed saving regret compared with $40 \%$ among those who neither agreed nor disagreed with the statement.

In Panel B, we show the estimates across seven statements about self-perceived behavior. These seven may have more validity than the five in Panel A because they ask about what individuals have actually done rather than self-perception. Several would seem to apply directly to an inability to save such as "How often do you give up a task when it gets difficult?" In both the ALP and the SLP, we conducted comparisons between the reference category and the other three categories for each of the seven behaviors for a total of 21 comparisons. In the ALP there were four significant differences, but three were not of the anticipated sign. For example, among those who responded "most of the time" to the question "How often do you settle for mediocre results when you could do better?," $35 \%$ expressed saving regret compared with $53 \%$ among those who responded "sometimes." In the SLP, there were three significant comparisons, but just one had the anticipated sign: The rate of regret among those who always try several tasks but don't complete many was 15 percentage points higher than the reference group ("sometimes"). However, that group comprised just 1.4 percent of the population.

Table 4 shows the fraction expressing regret as a function of several attributes that perhaps could be called skills. In both the ALP and the SLP large fractions have missing values because the questions about these attributes were not on all the surveys: the data on those attributes had to be retrieved from other ALP and SLP surveys which were not taken by some of our respondents. The most frequent responses to planning horizon were "next few years" or " $5-10$ years." In the ALP there is 
a monotonic reduction in regret as the planning horizon increases, although no horizons are significant relative to the reference group. In the SLP, there is little variation in regret except at the long horizon of 10 years or more. In the ALP, regret declines monotonically as financial literacy increases, and the differences are large and significant. By contrast, in the SLP there is no consistent variation in regret as a function of financial literacy. Probability numeracy is a skill that ought to help people make better financial decisions, and it is associated with saving regret: in both the ALP and SLP those who had more correct answers on questions designed to test probability numeracy were less likely to express saving regret.

Table 5 shows the frequency of negative and positive shocks in the ALP and SLP, ordered from most frequent to least in the SLP, and the likelihood of expressing regret. The overall level of negative shocks is much higher in the ALP: $69 \%$ reported that they had such a shock that impacted their financial position compared with $46 \%$ in the SLP. Four shocks are related to the labor market. Their frequencies are higher in the ALP and their effects on saving regret are much larger. In the ALP, the frequency of saving regret among those who did not report a negative shock was 0.421 (see Table 7 , Panel B). Among those who experienced an unemployment shock (a spell "that cause their finances to turn out worse than expected"), the proportion who stated regret was 0.621 , a difference in the frequency of 0.20 . In Singapore, among those who did not experience a negative shock the frequency of expressing regret was 0.401 . Among those who experienced an unemployment shock, the frequency of expressing regret was 0.542 , an increase of 0.14 . The other labor market shocks, "health limited work," "retired too early," and "earnings less than expected," are stated more frequently in the 
ALP. Each also causes higher proportions of respondents in the ALP than in the SLP to express saving regret. Other shocks more common in the ALP than in the SLP include giving financial help to relatives, having unexpectedly high college costs, having a death in the family, and having a divorce or separation. The impact of such shocks on saving regret is substantial in the ALP, but negligible in the SLP. The frequency of a health care spending shock is about the same in both surveys, but the consequences for expressing regret are much greater in the ALP: an increase of 0.244 versus 0.097 .

A larger proportion of ALP respondents reported having a positive shock, and the shocks had a greater impact on saving regret. In the ALP, those who had any positive shock expressed regret 6 percentage points less often than the average, but a positive shock had essentially no effect on regret in the SLP. In both surveys, having good investments or a good business resulted in significant reductions in expressing regret, but relatively few SLP respondents gave such a report.

Table 6 shows the distribution of negative shocks and the associated likelihood of regret. In the ALP, $31 \%$ of the respondents had no shocks; in the SLP, $54 \%$ had none. Among those who did not have a shock the likelihood of regret was almost the same, 0.421 compared with 0.401 . Thus, a first explanation for the difference in the level of regret between the U.S. and Singapore is that many more in the U.S. had one or more negative shocks. The difference in shock prevalence is also seen at the upper tail of the distribution: $24 \%$ of the ALP respondents reported three or more shocks compared with just $10 \%$ in the SLP. Furthermore, the consequences of several shocks for saving regret are greater in the ALP: The likelihood of regret increases with the 
number of shocks, reaching 0.76 for five or more shocks, whereas the likelihood is approximately flat at 0.50 for any number of shocks in the SLP.

Table 7, Panel A, shows the joint distribution of any positive or negative shock. The likelihood of either type of shock is higher in the ALP. In the ALP, there is no correlation between negative or positive shocks. For example, the likelihood of a positive shock given a negative shock is 0.515 versus an unconditional probability of 0.519. But in the SLP, the correlation is positive: The likelihood of a positive shock given a negative shock is 0.29 versus an unconditional probability of 0.24 .

Panel B shows the likelihood of expressing regret. Reflecting the differences in the consequences of a shock, the variation is much greater in the ALP than in the SLP. The likelihood of regret is 0.39 among those who experienced a positive shock but not a negative shock; this is 30 percentage points less than the likelihood among those who experienced a negative shock but not a positive. In the SLP this difference is just 0.11 . The panel exhibits an odd result: In the SLP, those who experienced a positive shock express saving regret slightly more often than those who do not experience such a shock. Upon investigation of the details, we found that what we intended to be positive shocks were often the consequences of a negative shock. For example, among those who worked more than expected, which cet. par. would lead to greater lifetime resources and possibly reduce saving regret, $61 \%$ experienced a negative shock compared with $43 \%$ among those who did not work more than expected. The most common negative shock was "earnings were less than expected," suggesting that working more than expected was a response to a shortfall in earnings. Similarly, receiving financial help from family, which would be an increase in lifetime resources, 
was associated with a greater likelihood of experiencing a negative shock, and the increase was greatest for "health limited work," followed by "large health expense." There is a similar although less pronounced tendency in the ALP: Among those who worked more than expected, $80 \%$ experienced a negative shock compared with $67 \%$ among those who did not work more than expected.

To check which of our main results are robust to controls for correlations among the explanatory variables, we estimated regressions of the probability of regret on the explanatory variables discussed in the preceding tables. The complete results are in the Appendix. Table 8 has excerpts from those regressions. We entered the psychometric variables linearly, scaled from 1 to 5 for the first group and from 1 to 4 for the second group. Our priors for the first group are that the coefficients on "self-confident" and "avoid unhealthy food or behaviors" would be negative and that the coefficient on "do what you like today, don't put it off," "works best under pressure," and "life is about having fun" would be positive. In the second group, our priors were that all would be positive. We estimated regressions that did and did not include wealth quartiles, but the differences are negligible.

In the ALP in group 1, two coefficients are statistically significant and in accord with our priors. The first, self-confident, has a negative coefficient; the second, works best under pressure, has a positive coefficient. The other coefficients are not significant and have a mix of signs with respect to conforming to priors. The coefficients that are significant in the ALP are not significant in the SLP, and those significant in the SLP are not significant in the ALP. Of the three that are significant in the SLP, only one, "Do what you like today..." has the anticipated sign. 
In the second ALP group, one coefficient is significant but it does not have the anticipated sign: Those who tend to settle for mediocre results report less regret. Ignoring significance levels, we find that three of the seven estimated coefficients have the anticipated sign. In the SLP, the one significant coefficient, "settle for mediocre results," has the opposite sign from that in the ALP.

As for the effect of any negative shock, our regression results that do not control for wealth quartile are similar to the results evident in the cross-tabs of Table 6 . The effect of any positive shock in the ALP is somewhat attenuated but remains significant both statistically and in magnitude.

\section{Discussion}

Overall, we find saving regret is substantially lower in Singapore than in the U.S. This may be a result of long-term economic conditions in each nation. The Singapore economy has grown greatly for many years, possibly leading to a current financial position that is better than many had expected. By contrast, since 1973 the U.S. has had periods of a stagnating economy with periods of quite high unemployment, possibly leading to a current financial position that is worse than many expected. The Great Recession appears to be particularly relevant for this observation: Our U.S sample of 60 to 74 year olds would have been in prime saving years for retirement at the time of the downturn.

Although both economies are market-driven and place considerable weight on self-reliance, Singapore has an important forced saving mechanism, the CPF. While the U.S. Social Security system may be even more important for retirement saving than the CPF, particularly for low-income individuals because of the progressivity in its benefit 
schedule, it does not force saving for health care or as a buffer for negative economic shocks.

Actual saving outcomes in the U.S. and Singapore are similar, but the components of saving differ substantially. According to the 2018 SLP survey, median wealth in our target population was $\$ 613,000$, converted from Singapore dollars to 2018 U.S. dollars using purchasing power parity. Median values of the components of wealth were $\$ 377,000$, housing; $\$ 116,000$, CPF wealth; and $\$ 38,000$, financial wealth. Median wealth in the U.S. in the 2016 HRS was $\$ 559,000$. Median values of components were $\$ 120,000$, housing; $\$ 260,000$, Social Security wealth: and $\$ 59,000$, financial wealth. ${ }^{6}$ Although the median wealth values are similar, the heavy concentration of wealth in housing renders Singaporeans effectively poorer because they must finance nonhousing consumption out of much less wealth. At the same time, because health care can be paid from CPF savings, and because health care is so much cheaper in Singapore than in the U.S., Singaporeans are perhaps better able to self-finance their health care. While nearly all U.S. retired persons have Medicare, $8.6 \%$ of total spending by those 55 to 64 and $12.3 \%$ of total spending by those 65 to 74 was on out-of-pocket medical expenses.

Shocks appear to be quite important in both countries. Among SLP respondents, $46 \%$ had a negative shock that affected their financial position; among ALP respondents, $69 \%$ had one. The effect of shocks was not symmetric; very few reported they wished that they had saved less. Shocks did have a smaller impact on saving

\footnotetext{
${ }^{6}$ The HRS total wealth does not include a wealth equivalent of DB pension entitlements, DC pension balances from prior jobs (just the current job), nor a wealth equivalent to a claim on Medicare benefits.
} 
regret among SLP respondents, which is consistent with shocks for SLP respondents being less severe. Some institutional reasons may also contribute to shocks having less of an impact in Singapore. In 2017, Singapore spent just 4.4\% of GDP on health care while the U.S. spent $17.9 \%$. As a result, the forced contributions to saving in MediSave coupled with possibly some small co-pays could shield many Singaporeans from health care spending shocks.

College expenses may also cause greater shocks in the U.S. than in Singapore. Between 1989 and 2016, the cost of attending a four-year university in the U.S. doubled in real terms while median real wages barely increased. ${ }^{7}$ In Singapore, tuition at the five autonomous universities increased by $14 \%$ in real terms between 2007 and 2016, but median wages increased by $23 \%$ in real terms. As a result, college education became more affordable in Singapore but less affordable in the U.S.

Another large difference between the U.S. and Singapore is the frequency of a death in the family (likely widowing but not specifically asked) and of divorce. Both are more frequent in the U.S., and the effects of each on saving regret is higher in the U.S. Labor market shocks are another difference between the countries: such shocks are more frequent in the U.S., and the effect on saving regret is greater.

We did not find that psychometric variables explain much of saving regret in either the U.S. or Singapore. We conclude that a battery of measures of procrastination, or a tendency not to tackle difficult tasks as measured by 12 indicators, were of little use in distinguishing persons who would have liked to have saved more from those who

\footnotetext{
${ }^{7}$ https://www.forbes.com/sites/camilomaldonado/2018/07/24/price-of-college-increasing-almost8-times-faster-than-wages/\#30efd6b66c1d
} 
were satisfied with their saving behavior. Our second conclusion is that to understand economic preparation for retirement we need to understand better the role of shocks. Part of that understanding is to learn more about individual expectations regarding lifetime shocks and their understanding of the consequences of shocks. An approach undertaken by government in Singapore is to force people to engage in buffer stock saving, but this is easier to do when an important sector, health care, is so much cheaper. 


\section{References}

Chetty, Raj, John N Friedman, Søren Leth-Petersen, Torben Heien Nielsen, and Tore Olsen. "Active Vs. Passive Decisions and Crowd-out in Retirement Savings Accounts: Evidence from Denmark." The Quarterly Journal of Economics 129, no. 3 (2014): 1141-219.

Hurd, Michael and Susann Rohwedder," Measuring Total Household Spending in a Monthly Internet Survey: Evidence from the American Life Panel," in Improving the Measurement of Consumer Expenditures, Eds. Christopher Carroll, Thomas Crossley and John Sabelhaus, University of Chicago Press, 2015, pp. 365-387.

Hurd, Michael and Susann Rohwedder, "The Impact of Unemployment on Income, Spending and Subjective Well-Being," presentation at "Japan-Singapore Health \& Labour Policy Roundtable," August 30, 2018. Center for Research on the Economics of Ageing, Singapore Management University.

Laibson, David. "Golden Eggs and Hyperbolic Discounting." The Quarterly Journal of Economics 112, no. 2 (1997): 443-78.

Laibson, David. "Life-Cycle Consumption and Hyperbolic Discount Functions." European Economic Review 42, no. 3-5 (1998): 861-71.

Laibson, David I, Andrea Repetto, Jeremy Tobacman, Robert E Hall, William G Gale, and George A Akerlof. "Self-Control and Saving for Retirement." Brookings Papers on Economic Activity 1998, no. 1 (1998): 91-196.

Lewis, Carol. "Why Barack Obama and David Cameron Are Keen To 'nudge' you." Times Online, July 142008.

Pollard, Michael S. and Matthew D. Baird, The RAND American Life Panel: Technical Description. Santa Monica, CA: RAND Corporation, 2017. https://www.rand.org/pubs/research_reports/RR1651.html. 
Thaler, Richard H. "Psychology and Savings Policies." The American Economic Review 84, no. 2 (1994): 186-92.

Thaler, Richard H, and Hersh M Shefrin. "An Economic Theory of Self-Control." Journal of Political Economy 89, no. 2 (1981): 392-406.

Thaler, Richard H, and Cass R Sunstein. "Libertarian Paternalism." American Economic Review 93, no. 2 (2003): 175-79.

Thaler, Richard H, and Cass R Sunstein. 2009. Nudge: Improving Decisions About Health, Wealth, and Happiness: Penguin.

Tuckman, B. W. (1991). The development and concurrent validity of the Procrastination Scale. Educational and Psychological Measurement, 51, 473-480.

Vaithianathan, Rhema, Bryce Hool, Michael D. Hurd, and Susann Rohwedder. (2018). High-Frequency Internet Survey of a Probability Sample of Older Singaporeans: The Singapore Life Pane ${ }^{\circledR}$. The Singapore Economic Review, Special Edition on Economic Issues of Population Aging in Asia. https://doi.org/10.1142/S0217590818420043. 


\section{Table 1: Prevalence of saving regret, before and after revision}

\begin{tabular}{|c|c|c|c|c|}
\hline \multirow[b]{3}{*}{ Wish to have } & \multicolumn{2}{|c|}{ ALP } & \multicolumn{2}{|c|}{ SLP } \\
\hline & \multicolumn{2}{|c|}{ Total } & \multicolumn{2}{|c|}{ Total } \\
\hline & $\begin{array}{l}\text { before } \\
\text { revision }\end{array}$ & $\begin{array}{l}\text { after } \\
\text { revision }\end{array}$ & $\begin{array}{l}\text { before } \\
\text { revision }\end{array}$ & $\begin{array}{l}\text { after } \\
\text { revision }\end{array}$ \\
\hline ...saved more & 66.0 & 54.2 & 53.3 & 45.5 \\
\hline $\begin{array}{l}\text {...about the } \\
\text { same }\end{array}$ & 32.5 & 44.3 & 42.4 & 50.1 \\
\hline ...saved less & 1.5 & 1.5 & 4.4 & 4.4 \\
\hline Total & 100.0 & 100.0 & 100.0 & 100.0 \\
\hline $\mathbf{N}$ & 2,618 & & 4,559 & \\
\hline
\end{tabular}

Note: In the SLP respondents were asked whether they would "Spend less and save more over the years?" which we call the framed version of the question. In the ALP a random half sample were asked the framed version; the other half were asked whether they would "Save more over the years?" which we call the unframed version. The ALP results combine both random subsamples. 
Table 2: Saving regret by sociodemographic characteristics

\begin{tabular}{|c|c|c|c|c|c|c|c|c|c|c|}
\hline & \multirow[b]{3}{*}{$\mathrm{N}$} & \multirow[b]{3}{*}{$\begin{array}{c}\text { In } \\
\text { percent }\end{array}$} & \multicolumn{3}{|l|}{ ALP } & \multirow[b]{3}{*}{$\mathrm{N}$} & \multicolumn{4}{|c|}{ SLP } \\
\hline & & & \multicolumn{3}{|c|}{$\begin{array}{c}\text { Saving Regret (After } \\
\text { Revision) }\end{array}$} & & \multirow[b]{2}{*}{$\begin{array}{c}\text { In } \\
\text { percent }\end{array}$} & \multicolumn{3}{|c|}{$\begin{array}{c}\text { Saving Regret (After } \\
\text { Revision) } \\
\end{array}$} \\
\hline & & & Mean & Std. Error & $\begin{array}{c}\mathrm{T}- \\
\text { test } \\
\end{array}$ & & & Mean & $\begin{array}{l}\text { Std. } \\
\text { Error }\end{array}$ & $\begin{array}{l}\mathrm{T}- \\
\text { test } \\
\end{array}$ \\
\hline Total & 2,618 & 100.0 & 0.542 & 0.015 & & 4,558 & 100.0 & 0.455 & 0.007 & \\
\hline \multicolumn{11}{|l|}{ Female } \\
\hline 0 & 1,246 & 47.6 & 0.526 & 0.025 & ref & 2,247 & 49.3 & 0.465 & 0.011 & ref \\
\hline 1 & 1,372 & 52.4 & 0.557 & 0.019 & ns & 2,311 & 50.7 & 0.446 & 0.010 & ns \\
\hline \multicolumn{11}{|l|}{ Age } \\
\hline $60-64$ & 1,058 & 40.4 & 0.581 & 0.024 & ref & 2,137 & 46.9 & 0.467 & 0.011 & ref \\
\hline 65-69 & 926 & 35.4 & 0.531 & 0.024 & ns & 1,514 & 33.2 & 0.444 & 0.013 & ns \\
\hline 70-74 & 634 & 24.2 & 0.494 & 0.032 & $* *$ & 907 & 19.9 & 0.448 & 0.017 & ns \\
\hline \multicolumn{11}{|l|}{ Marital status } \\
\hline Married & 1,747 & 66.7 & 0.517 & 0.019 & ref & 3,542 & 77.7 & 0.454 & 0.008 & ref \\
\hline separated or divorced & 505 & 19.3 & 0.625 & 0.030 & $* * *$ & 364 & 8.0 & 0.481 & 0.026 & ns \\
\hline Widowed & 242 & 9.2 & 0.617 & 0.048 & $*$ & 227 & 5.0 & 0.463 & 0.033 & ns \\
\hline never married & 120 & 4.6 & 0.426 & 0.068 & ns & 421 & 9.2 & 0.444 & 0.024 & ns \\
\hline Missing & 4 & 0.2 & 0.000 & 0.000 & $* * *$ & 4 & 0.1 & 0.250 & 0.217 & \\
\hline \multicolumn{11}{|l|}{ Education terciles } \\
\hline Lowest & 874 & 33.4 & 0.528 & 0.034 & ref & 1,520 & 33.3 & 0.447 & 0.013 & ref \\
\hline 2 & 871 & 33.3 & 0.605 & 0.023 & $*$ & 1,519 & 33.3 & 0.460 & 0.013 & ns \\
\hline Highest & 873 & 33.3 & 0.494 & 0.017 & ns & 1,519 & 33.3 & 0.460 & 0.013 & ns \\
\hline \multicolumn{11}{|l|}{ Wealth quartiles } \\
\hline Lowest & 328 & 12.5 & 0.595 & 0.048 & ref & 1,150 & 25.2 & 0.463 & 0.015 & ref \\
\hline 2 & 323 & 12.3 & 0.654 & 0.045 & ns & 1,129 & 24.8 & 0.469 & 0.015 & ns \\
\hline 3 & 323 & 12.3 & 0.559 & 0.040 & ns & 1,133 & 24.9 & 0.495 & 0.015 & ns \\
\hline Highest & 324 & 12.4 & 0.355 & 0.038 & $* * *$ & 1,129 & 24.8 & 0.398 & 0.015 & $* * *$ \\
\hline Missing & 1,320 & 50.4 & 0.544 & 0.021 & $\mathrm{~ns}$ & 17 & 0.4 & 0.294 & 0.111 & ns \\
\hline \multicolumn{11}{|l|}{ Income quartiles } \\
\hline Lowest & 670 & 25.6 & 0.507 & 0.034 & ref & 1,022 & 22.4 & 0.465 & 0.016 & ref \\
\hline 2 & 688 & 26.3 & 0.595 & 0.031 & $*$ & 1,020 & 22.4 & 0.441 & 0.016 & ns \\
\hline 3 & 585 & 22.4 & 0.558 & 0.028 & ns & 1,038 & 22.8 & 0.486 & 0.016 & ns \\
\hline Highest & 642 & 24.5 & 0.508 & 0.023 & ns & 986 & 21.6 & 0.440 & 0.016 & ns \\
\hline Missing & 33 & 1.3 & 0.535 & 0.142 & ns & 492 & 10.8 & 0.433 & 0.022 & ns \\
\hline \multicolumn{11}{|l|}{ Fair or poor health } \\
\hline 0 & 2,029 & 77.5 & 0.533 & 0.017 & ref & 2,782 & 61.0 & 0.430 & 0.009 & ref \\
\hline 1 & 589 & 22.5 & 0.576 & 0.034 & ns & 1,776 & 39.0 & 0.495 & 0.012 & $* * *$ \\
\hline \multicolumn{11}{|l|}{ Fair or poor memory } \\
\hline 0 & 2,199 & 84.0 & 0.537 & 0.017 & ref & & & & & \\
\hline 1 & 285 & 10.9 & 0.512 & 0.048 & ns & & & & & \\
\hline Missing & 134 & 5.1 & 0.698 & 0.043 & $* * *$ & & & & & \\
\hline
\end{tabular}

Note: ${ }^{* *}=p$-value $<0.01 ;{ }^{* *}=p$-value $<0.05 ;{ }^{*}=p$-value $<0.10$ 
Table 3: Saving regret by personality traits

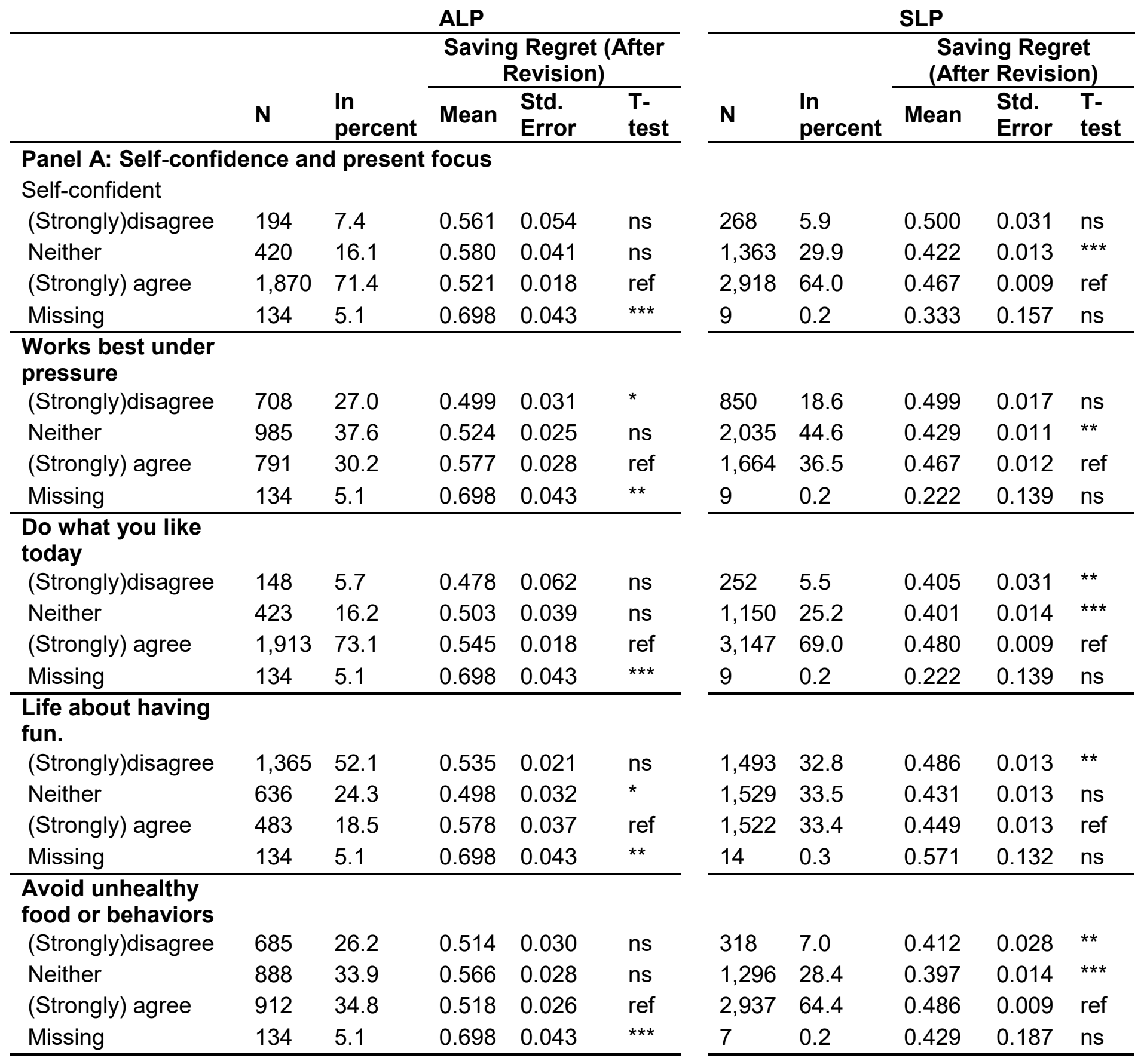

Note: ${ }^{* * *}=p$-value $<0.01 ;{ }^{* *}=p$-value $<0.05 ;{ }^{*}=p$-value $<0.10$ 


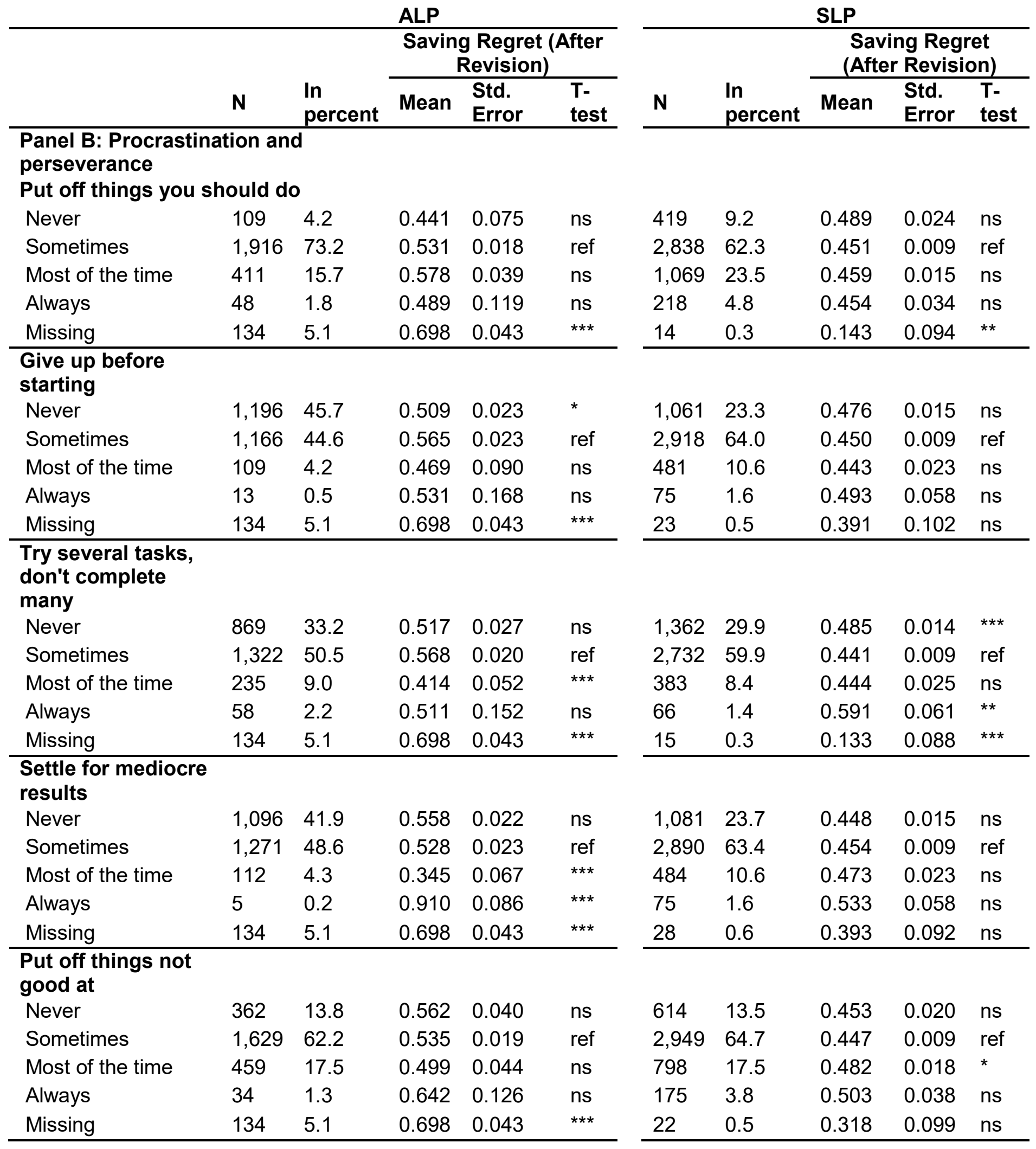




\begin{tabular}{|c|c|c|c|c|c|c|c|c|c|c|}
\hline \multicolumn{11}{|l|}{$\begin{array}{l}\text { Put off difficult } \\
\text { things }\end{array}$} \\
\hline Never & 1,086 & 41.5 & 0.546 & 0.025 & ns & 1,084 & 23.8 & 0.484 & 0.015 & ** \\
\hline Sometimes & 1,204 & 46.0 & 0.527 & 0.022 & ref & 2,890 & 63.4 & 0.440 & 0.009 & ref \\
\hline Most of the time & 175 & 6.7 & 0.490 & 0.069 & ns & 476 & 10.4 & 0.479 & 0.023 & ns \\
\hline Always & 20 & 0.8 & 0.667 & 0.150 & ns & 89 & 2.0 & 0.528 & 0.053 & * \\
\hline Missing & 134 & 5.1 & 0.698 & 0.043 & $* * *$ & 19 & 0.4 & 0.263 & 0.101 & ns \\
\hline \multicolumn{11}{|l|}{$\begin{array}{l}\text { Lose motivation } \\
\text { during tasks }\end{array}$} \\
\hline Never & 846 & 32.3 & 0.558 & 0.027 & ns & 1,197 & 26.3 & 0.477 & 0.014 & * \\
\hline Sometimes & 1,525 & 58.2 & 0.534 & 0.020 & ref & 2,930 & 64.3 & 0.444 & 0.009 & ref \\
\hline Most of the time & 100 & 3.8 & 0.323 & 0.071 & $* * *$ & 358 & 7.9 & 0.480 & 0.026 & ns \\
\hline Always & 14 & 0.5 & 0.585 & 0.160 & ns & 53 & 1.2 & 0.509 & 0.069 & ns \\
\hline Missing & 134 & 5.1 & 0.698 & 0.043 & $* * *$ & 20 & 0.4 & 0.300 & 0.102 & ns \\
\hline
\end{tabular}

Note: ${ }^{* *}=p$-value $<0.01 ;{ }^{* *}=p$-value $<0.05 ;{ }^{*}=p$-value $<0.10$ 
Table 4. Saving regret by financial planning horizon,

financial literacy and numeracy

ALP

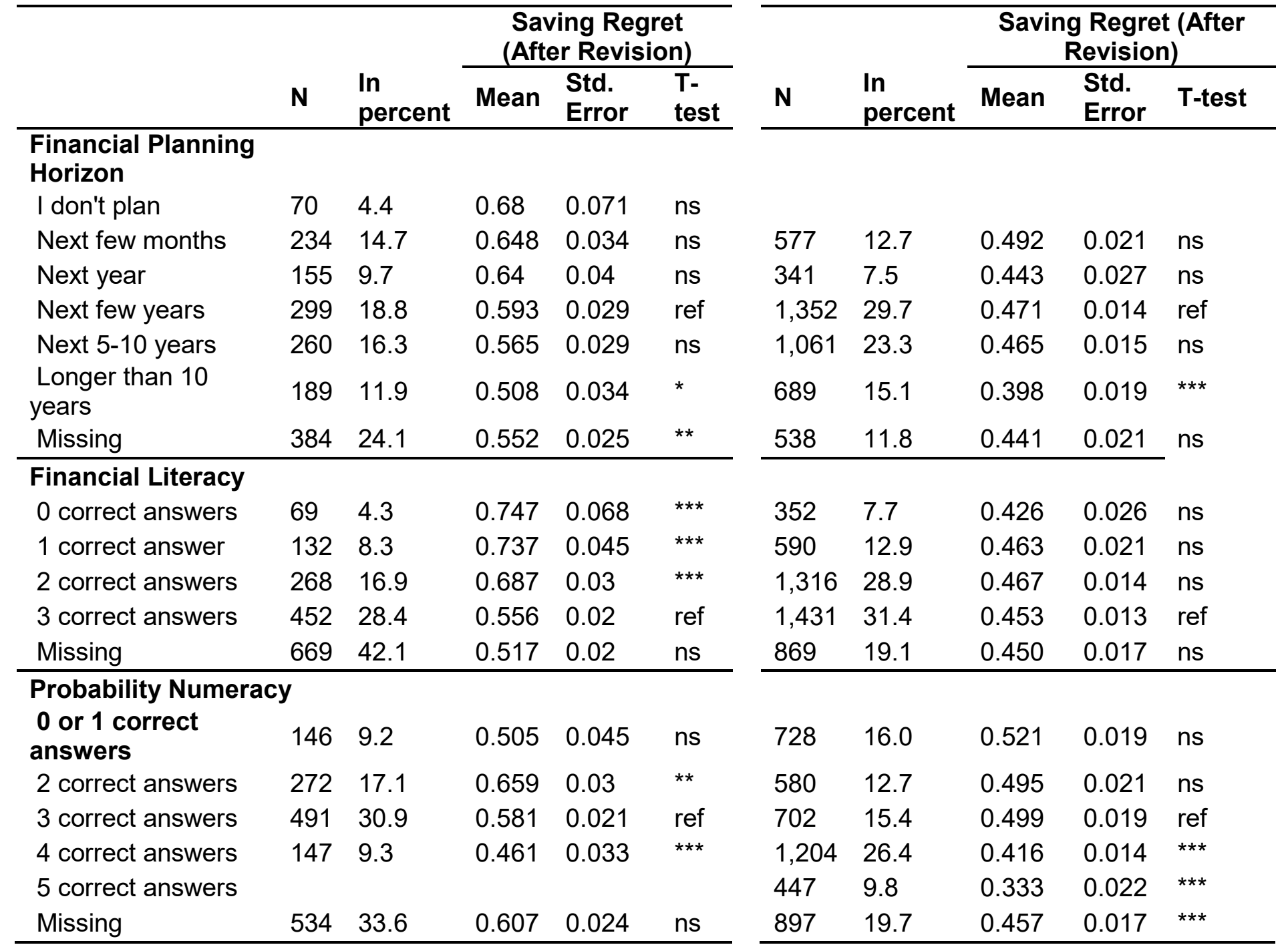

Note: ${ }^{* *}=p$-value $<0.01 ;{ }^{* *}=p$-value $<0.05 ;{ }^{*}=p$-value $<0.10$ 
Table 5: Saving regret and negative/positive shocks

\begin{tabular}{|c|c|c|c|c|c|c|c|c|c|c|}
\hline & \multicolumn{5}{|c|}{ ALP } & \multicolumn{5}{|c|}{ SLP } \\
\hline & \multirow[t]{2}{*}{$\mathbf{N}$} & \multirow[t]{2}{*}{$\begin{array}{l}\text { In } \\
\text { percent }\end{array}$} & \multicolumn{3}{|c|}{$\begin{array}{l}\text { Saving Regret } \\
\text { (After Revision) }\end{array}$} & \multirow[t]{2}{*}{$\mathbf{N}$} & \multirow[t]{2}{*}{$\begin{array}{l}\text { In } \\
\text { percent }\end{array}$} & \multicolumn{3}{|c|}{$\begin{array}{l}\text { Saving Regret (After } \\
\text { Revision) }\end{array}$} \\
\hline & & & mean & $\begin{array}{l}\text { Std. } \\
\text { Error }\end{array}$ & $\begin{array}{l}\text { T- } \\
\text { test }\end{array}$ & & & mean & $\begin{array}{l}\text { Std. } \\
\text { Error }\end{array}$ & T-test \\
\hline \multicolumn{11}{|l|}{ Negative Shocks } \\
\hline \multirow{2}{*}{$\begin{array}{l}\text { Health limited work } \\
\text { Earnings less than } \\
\text { expected }\end{array}$} & 452 & 19.8 & 0.622 & 0.037 & $* *$ & 641 & 14.1 & 0.524 & 0.020 & $* * *$ \\
\hline & 353 & 15.5 & 0.672 & 0.035 & $* * *$ & 565 & 12.4 & 0.566 & 0.021 & $* * *$ \\
\hline Unemployment & 415 & 18.1 & 0.621 & 0.031 & $* *$ & 515 & 11.3 & 0.542 & 0.022 & $* * *$ \\
\hline Large health expense & 233 & 10.2 & 0.665 & 0.043 & $* * *$ & 478 & 10.5 & 0.498 & 0.023 & $* *$ \\
\hline \multirow{2}{*}{$\begin{array}{l}\text { Retired too early } \\
\text { Financial help to } \\
\text { relatives }\end{array}$} & 301 & 13.2 & 0.643 & 0.050 & ** & 377 & 8.3 & 0.599 & 0.025 & $* * *$ \\
\hline & 396 & 17.3 & 0.661 & 0.041 & $* * *$ & 352 & 7.7 & 0.497 & 0.027 & ns \\
\hline \multirow{3}{*}{$\begin{array}{l}\text { Bad investment } \\
\text { Large (non-health/educ) } \\
\text { expense } \\
\text { College costs higher } \\
\text { than expected }\end{array}$} & 242 & 10.6 & 0.673 & 0.043 & $* * *$ & 317 & 7.0 & 0.492 & 0.028 & ns \\
\hline & 177 & 7.8 & 0.642 & 0.043 & ** & 217 & 4.8 & 0.525 & 0.034 & $* *$ \\
\hline & 211 & 9.2 & 0.673 & 0.042 & $* * *$ & 192 & 4.2 & 0.469 & 0.036 & ns \\
\hline Death in family & 279 & 12.2 & 0.665 & 0.043 & $* * *$ & 193 & 4.2 & 0.451 & 0.036 & ns \\
\hline Divorce/separation & 443 & 19.4 & 0.634 & 0.032 & $* * *$ & 69 & 1.5 & 0.435 & 0.060 & ns \\
\hline Other & 23 & 1.0 & 0.682 & 0.103 & ns & 40 & 0.9 & 0.325 & 0.074 & * \\
\hline Any negative shock & 1,582 & 69.1 & 0.608 & 0.020 & $* * *$ & 2,084 & 45.9 & 0.520 & 0.011 & $* * *$ \\
\hline \multicolumn{11}{|l|}{ Positive Shocks } \\
\hline $\begin{array}{l}\text { Spent less than } \\
\text { expected }\end{array}$ & 335 & 14.7 & 0.549 & 0.049 & ns & 762 & 16.7 & 0.503 & 0.018 & $* * *$ \\
\hline $\begin{array}{l}\text { Respondent worked } \\
\text { longer than expected }\end{array}$ & 400 & 17.5 & 0.533 & 0.038 & ns & 646 & 14.2 & 0.488 & 0.020 & * \\
\hline $\begin{array}{l}\text { Received financial help } \\
\text { from family } \\
\text { Respondent }\end{array}$ & 188 & 8.2 & 0.570 & 0.046 & ns & 502 & 11.0 & 0.512 & 0.022 & $* * *$ \\
\hline $\begin{array}{l}\text { salary/earnings more } \\
\text { than expected }\end{array}$ & 545 & 23.8 & 0.481 & 0.034 & $* *$ & 483 & 10.6 & 0.460 & 0.023 & ns \\
\hline $\begin{array}{l}\text { Good } \\
\text { investments/business }\end{array}$ & 539 & 23.5 & 0.403 & 0.031 & $* * *$ & 405 & 8.9 & 0.388 & 0.024 & $* * *$ \\
\hline $\begin{array}{l}\text { Spouse worked longer } \\
\text { than expected }\end{array}$ & 257 & 11.2 & 0.503 & 0.061 & ns & 288 & 6.3 & 0.500 & 0.029 & ns \\
\hline $\begin{array}{l}\text { Spouse salary/earnings } \\
\text { more than expected }\end{array}$ & 372 & 16.3 & 0.487 & 0.045 & ns & 259 & 5.7 & 0.502 & 0.031 & ns \\
\hline $\begin{array}{l}\text { Received an } \\
\text { inheritance }\end{array}$ & 530 & 23.2 & 0.467 & 0.032 & $* * *$ & 148 & 3.3 & 0.432 & 0.041 & ns \\
\hline Other & 16 & 0.7 & 0.659 & 0.137 & ns & 54 & 1.2 & 0.426 & 0.067 & ns \\
\hline Any positive shock & 1,188 & 51.9 & 0.488 & 0.022 & $* * *$ & 1,074 & 23.6 & 0.461 & 0.015 & ns \\
\hline \multicolumn{11}{|l|}{ All } \\
\hline & 2,290 & 100.0 & 0.550 & 0.017 & & 4,558 & 100.0 & 0.455 & 0.007 & \\
\hline
\end{tabular}

Note: ${ }^{* * *}=p$-value $<0.01 ;{ }^{* *}=p$-value $<0.05 ;{ }^{*}=p$-value $<0.10$ 
Table 6: Saving regret by number of negative shocks

\begin{tabular}{|c|c|c|c|c|c|c|c|c|c|c|}
\hline & \multicolumn{5}{|c|}{ ALP } & \multicolumn{5}{|c|}{ SLP } \\
\hline & \multirow[t]{2}{*}{$\mathbf{N}$} & \multirow[t]{2}{*}{$\begin{array}{l}\text { In } \\
\text { percent }\end{array}$} & \multicolumn{3}{|c|}{$\begin{array}{l}\text { Saving Regret } \\
\text { (After Revision) }\end{array}$} & \multirow[t]{2}{*}{$\mathbf{N}$} & \multirow[t]{2}{*}{$\begin{array}{l}\text { In } \\
\text { percent }\end{array}$} & \multicolumn{3}{|c|}{$\begin{array}{l}\text { Saving Regret (After } \\
\text { Revision) }\end{array}$} \\
\hline & & & mean & $\begin{array}{l}\text { Std. } \\
\text { Error }\end{array}$ & $\begin{array}{l}\text { T- } \\
\text { test }\end{array}$ & & & mean & $\begin{array}{l}\text { Std. } \\
\text { Error }\end{array}$ & T-test \\
\hline \multicolumn{11}{|c|}{$\begin{array}{l}\text { Number of Negative } \\
\text { Shocks }\end{array}$} \\
\hline 0 & 708 & 30.9 & 0.421 & 0.031 & ref & 2,461 & 54.0 & 0.401 & 0.010 & ref \\
\hline 1 & 634 & 27.7 & 0.538 & 0.035 & $* *$ & 1,098 & 24.1 & 0.507 & 0.015 & $* * *$ \\
\hline 2 & 408 & 17.8 & 0.613 & 0.036 & $* * *$ & 514 & 11.3 & 0.537 & 0.022 & $* * *$ \\
\hline 3 & 267 & 11.7 & 0.617 & 0.040 & $* * *$ & 245 & 5.4 & 0.567 & 0.032 & $* * *$ \\
\hline 4 & 157 & 6.8 & 0.738 & 0.045 & $* * *$ & 123 & 2.7 & 0.480 & 0.045 & $*$ \\
\hline 5 plus & 111 & 4.9 & 0.763 & 0.051 & $* * *$ & 104 & 2.3 & 0.500 & 0.049 & ** \\
\hline Missing & 5 & 0.2 & 1.000 & 0.000 & *** & 13 & 0.3 & 0.462 & 0.138 & ns \\
\hline Total & 2,290 & 100.0 & 0.550 & 0.017 & & 4,558 & 100.0 & 0.455 & 0.007 & \\
\hline
\end{tabular}

Table 7: Saving regret and the experience of at least one negative/positive shock

ALP
$\begin{aligned} & \text { Panel A: Distribution of Population According to } \\
& \text { Whether Positive or Negative Shock Was } \\
& \text { Experienced (Weighted) }\end{aligned}$
\begin{tabular}{llll}
\multicolumn{4}{c}{ negative } \\
positive & No & yes & total \\
\cline { 2 - 4 } No & 14.59 & 33.49 & 48.08 \\
Yes & 16.34 & 35.57 & 51.92 \\
total & 30.94 & 69.06 & 100.00 \\
& & & \\
\hline
\end{tabular}
SLP

Panel A: Distribution of Population According to Whether Positive or Negative Shock Was Experienced (Unweighted)

\begin{tabular}{llll}
\hline \multirow{2}{*}{$\begin{array}{llll}\text { positive } \\
\text { no }\end{array}$} & \multicolumn{3}{c}{ nogative } \\
\cline { 2 - 4 } yes & 43.71 & 32.68 & total \\
yes & 10.44 & 13.17 & 76.39 \\
total & 54.15 & 45.85 & 100.61 \\
\end{tabular}

Panel B: Mean Saving Regret According to Positive or Negative Shock (Weighted)

Panel B: Mean Saving Regret According to Positive or Negative Shock (Unweighted)

\begin{tabular}{llll} 
& \multicolumn{3}{c}{ negative } \\
positive & no & yes & total \\
\cline { 2 - 4 } No & 0.460 & 0.687 & 0.618 \\
Yes & 0.387 & 0.535 & 0.488 \\
total & 0.421 & 0.608 & 0.550 \\
\hline
\end{tabular}

\begin{tabular}{llll} 
& \multicolumn{3}{c}{ negative } \\
positive & no & yes & total \\
\cline { 2 - 4 } no & 0.398 & 0.528 & 0.453 \\
yes & 0.414 & 0.498 & 0.461 \\
total & 0.401 & 0.519 & 0.455 \\
\hline
\end{tabular}


Table 8: Extracts from regressions - effect on probability of expressing

saving regret

\begin{tabular}{|c|c|c|c|c|}
\hline & \multirow{2}{*}{\multicolumn{2}{|c|}{ ALP }} & \multirow{2}{*}{\multicolumn{2}{|c|}{ SLP }} \\
\hline & & & & \\
\hline & Model 1 & Model 2 & Model 1 & Model 2 \\
\hline \multicolumn{5}{|l|}{$\begin{array}{l}\text { Self-confidence and present focus } \\
\text { (Scaled 1-5 from "Strongly Disagree" } \\
\text { to "Strongly Agree") }\end{array}$} \\
\hline Self-confident & $-0.0547^{* * *}$ & $-0.0469^{* *}$ & -0.00600 & -0.00517 \\
\hline Works best under pressure & $0.0459^{* * *}$ & $0.0467^{* * *}$ & -0.00747 & -0.00711 \\
\hline $\begin{array}{l}\text { Do what you like today, don't put it } \\
\text { off }\end{array}$ & 0.0243 & 0.0215 & $0.0394^{* * *}$ & $0.0406^{* * *}$ \\
\hline Life is about having fun & 0.000819 & -0.000302 & $-0.0149^{*}$ & $-0.0150^{*}$ \\
\hline Avoid unhealthy food or behaviors & 0.0103 & 0.00862 & $0.0471^{* * *}$ & $0.0474^{* * *}$ \\
\hline \multicolumn{5}{|l|}{$\begin{array}{l}\text { Procrastination and perseverance } \\
\text { (Scaled 1-4 from "Never" to } \\
\text { "Always") }\end{array}$} \\
\hline Put off things you should do & 0.0333 & 0.0300 & $-0.0233^{*}$ & $-0.0203^{*}$ \\
\hline Give up before starting & 0.0401 & 0.0443 & 0.00469 & 0.00369 \\
\hline $\begin{array}{l}\text { Try several tasks, don't complete } \\
\text { many }\end{array}$ & -0.00935 & -0.00881 & -0.0176 & -0.0173 \\
\hline Settle for mediocre results & $-0.0507^{*}$ & $-0.0498^{*}$ & $0.0234^{* *}$ & $0.0228^{* *}$ \\
\hline Put off things not good at & 0.0174 & 0.0159 & 0.0180 & $0.0209^{*}$ \\
\hline Give up task when difficult & -0.0176 & -0.0132 & -0.0111 & -0.0121 \\
\hline Lose motivation during tasks & -0.0374 & -0.0390 & -0.00654 & -0.00902 \\
\hline Negative shock & $0.186^{* \star *}$ & $0.173^{\star * *}$ & $0.112^{* \star *}$ & $0.108^{* * *}$ \\
\hline Positive shock & $-0.110^{* * *}$ & $-0.0941^{* * *}$ & -0.00336 & 0.0105 \\
\hline Wealth included & $\mathrm{N}$ & $\mathrm{Y}$ & $\mathrm{N}$ & $\mathrm{Y}$ \\
\hline Observations & 2436 & 2436 & 4514 & 4514 \\
\hline R2 & 0.106 & 0.119 & 0.0365 & 0.0421 \\
\hline \multicolumn{5}{|l|}{ F-tests } \\
\hline $\begin{array}{l}\text { joint significance psychometric } \\
\text { scales }\end{array}$ & $\begin{array}{l}F(12,1411)= \\
2.22 \\
\text { Prob }>F= \\
0.0093 \\
F(28,1411)= \\
7.58\end{array}$ & $\begin{array}{l}F(12,1411) \\
=1.96 \\
\text { Prob }>F= \\
0.0242 \\
F(32,1411) \\
=7.61\end{array}$ & $\begin{array}{l}F(12,4487) \\
=4.99 \\
\text { Prob }>F= \\
0.0000 \\
F(26,4487) \\
=6.53\end{array}$ & $\begin{array}{l}F(12,4483)= \\
5.18 \\
\text { Prob }>F= \\
0.0000 \\
F(30,4483)= \\
6.56\end{array}$ \\
\hline joint significance full model & $\begin{array}{l}\text { Prob }>F= \\
0.0000\end{array}$ & $\begin{array}{l}\text { Prob }>F= \\
0.000\end{array}$ & $\begin{array}{l}\text { Prob }>F= \\
0.0000\end{array}$ & Prob $>F=0.000$ \\
\hline
\end{tabular}

Note: ${ }^{* *}=p$-value $<0.01 ;{ }^{* *}=p$-value $<0.05 ;{ }^{*}=p$-value $<0.10$ 